\title{
Integration and Devolvement of Human \\ Resource Practices in Nepal
}

\author{
DHRUBA KUMAR GAUTAM \\ Tribhuvan University \\ Faculty of Management \\ P.O. Box 12719, Kathmandu, Nepal \\ Te: $977-1-4784933 / 9841367451$ \\ E-Mail: gautamdhruba@yahoo.com
}

\author{
Ann J Davis \\ Aston Business School \\ Aston University \\ Birmingham \\ UK \\ +441212043261 \\ Email: a.j.davis@aston.ac.uk
}

Paper for:

Special Issues of Employee Relations

"People Management in India and the Sub Continent" 2007 


\begin{abstract}
Purpose

The purpose of this study is to explore the nature of Human Resource Management in publicly listed finance sector companies in Nepal. In particular, it explores the extent to which HR practice is integrated into organisational strategy and devolved to line management.
\end{abstract}

\title{
Methodology
}

A structured interview was conducted with the senior executive responsible for Human Resource Management in 26 commercial banks and insurance companies in Nepal.

\section{Findings}

The degree of integration of HR practice appears to be increasing within this sector, but this is dependent on the maturity of the organisations. Devolvement of responsibility to line managers is at best partial and in the case of the insurance companies, more out of necessity due to the absence of a strong central HR function.

\section{Research limitations/Implications}

The survey is inevitably based on a small sample, however this represents $90 \%$ of the relevant population. The data suggest that Western HR is making inroads into more developed aspects of Nepalese business. Compared with Nepalese business as a whole, the financial sector appears relatively westernised, although Nepal still lags India in its uptake of HR practices.

\section{Practical implications}


It appears unlikely from a cultural perspective that devolvement of responsibility will be achieved as a result of HR strategy. National cultural, political and social factors continue to be highly influential in shaping the Nepalese business environment

\section{Originality}

Few papers have explored HR practice in Nepal. This paper contributes to the overall assessment of HR uptake globally and highlights emic features impacting on that uptake.

\section{Keywords}

Research paper, Nepal, HRM, Integration, Devolvement, 
Research into the management of human resources tends to focus on those practices and value systems which are dominant in Western Europe and North America, occasionally contrasting these with the tiger economies of south east Asia (china bein an exception in this regard). However, the validity and transportability of culturally dependent models and practices may be questioned (colloquium presentation). Within an internationalised business environment, India and the sub-continent has in recent years gained increasing significance within the "Global Business Village" (Budhwar and Debra, 2001), although her much smaller and rather inaccessible neighbour Nepal has still to see many of the proposed benefits. This article seeks therefore to examine the uptake of HR practices in Nepal and to explore the extent to which westerns models of HRM are applicable in such a context. In particular, it focuses on two key facets of HRM, integration and devolvement, and looks at whether and how these are operationalised in public limited banking and finance organisations in Nepal.

Western conceptions of HRM typically focus on the importance of integrating HRM into business and corporate strategy (and indeed integrating HRM policies and practises with each other) and devolving HRM activity to line managers instead of personnel specialists (Brewster and Larsen, 1992; Budhwar, 2000a). These dimensions imply a shift towards a more strategic role for HRM. Through integration, HRM becomes more embedded in the business strategy rather than a downstream or reactive activity, and following from this, HRM specialists become less focussed on routine HR activities, these responsibilities being devolved to line management. Therefore, the line management role becomes a strategic HR lever for the implementation of policy and strategy.

In line with the argument made by Budhwar and Sparrow (2002), we present HRM as context specific and contingent (Forster and Whipp, 1995). Nepal's context is one of hierarchy and 
bureaucracy, highly status conscious and somewhat risk averse. In focusing on public limited companies we seek to explore the development of HR in businesses that may be assumed to be making more attempts to break free of such historical ties and traditions, or at least to align more closely with the current global business environment. The combination of high uncertainty avoidance and power distance, coupled with a bureaucratic culture, would suggest that while the strategic integration of HRM would be attractive, the devolvement of responsibility would be more problematic.

The banking and finance sector has been chosen for this study both for its relatively large size, consistency in governance, and relative success within the rather weak Nepalese economy. These features go some way to controlling for sectoral, institutional and business environment factors (Budhwar and Sparrow, 2002).

\section{Strategic integration and devolvement in Human Resource Management}

Models of human resource management have been variously proposed, contested, and summarised by almost as many people as have written on the topic (Schuler, 1992; Storey, 1992; Lengnick-Hall and Lengnick-Hall, 1999). Stemming from work in the United States in the early 1980's, (Beer et al., 1985; Fombrun et al., 1994) and developing it the UK and Western Europe most notably by Guest $(1987 ; 1997)$, and Legge (1995) a number of themes have emerged which appear to mark out key dimensions in the concept. Perhaps the dominant theme has been that HRM should represent the strategic integration of people into the organisation, or "the degree to which the HRM issues are considered as part of the formulation of business strategies" (Brewster and Larsen, 1992 p411). While integration also operates at the level of the consistency and complementarity within and between HR policies 
and procedures (Guest 1987; Legge 1995), it is this strategic integration that is the focus of this study. This particular issue distinguishes HRM as a strategic approach to the management of people and opens the opportunity to view people as a basis of competitive advantage rather than merely a cost to be managed.

The desirability of such strategic integration is identified by Lengnick-Hall and LengnickHall (1999, p31) as follows.

"First, integration provides a broader range of solutions for solving complex organizational problems. Second, integration ensures that human, financial, and technological resources are given consideration in setting goals and assessing implementation capabilities. Third, through integration organizations must explicitly consider the individuals who comprise them and must implement policies. Finally, reciprocity in integrating human resource and strategic concerns limits the subordination of strategic considerations to human resource preferences and the neglect of human resources as a vital source of organizational competence and competitive advantage."

Such an elevated role for the HR specialist clearly ought to indicate a significant change of direction and emphasis away from the "routine" aspects of HR work that maintain the organisation (Boxall, 1994). Strategy is not seen as a classical top down process but as a dialogue between relevant parties, wherein the HR specialist does not simply respond to the whims of "strategists" but debates and informs the development of that strategy (Schuler, 1992). The representation of HR at director level is often taken to be an indication of the extent to which HR is at the heart of organisational strategy, along with the presence of HR strategy and the point at which HR is involved in strategic decision making (Brewster and Larsen, 1992; Brewster et al., 1997; Truss et al., 1997). 
Paradoxically, those activities through which strategy is delivered become, in an integrated context, simultaneously more significant in delivering strategy and yet distanced from the HR strategist role. It becomes line managers' responsibility to ensure that the strategic vision of the organisation is enacted on a day to day basis, hence the second theme of the devolvement of HRM responsibility to line management; "the degree to which HRM practice involves and gives responsibility to line managers rather than personnel specialists" (Brewster \& Larsen, 1992 p412). Indeed Guest's (1987) discussion of integration states that "Line managers must accept their responsibility to practise human resource management" (p512) while making use of functional specialists in respect of policy development or as a coordinator or catalyst (Schuler, 1990).

Such a shift requires both a devolvement of power on behalf of a central HR function and an increase in the skills and understanding of the line managers with respect to HR activities. However, there is doubt as to whether effective HRM can be delivered by line managers whose primary responsibility lies elsewhere, namely, in meeting service or production goals, and who have limited time for learning how to find ways to get the best out of their staff (Whittaker and Marchington, 2003). While some line managers are very enthusiastic about the idea of taking responsibility for HRM in their area, many are unhappy at the prospect. Gennard and Kelly (1997) identify that while many line managers are on the whole content to take on the "comfortable" aspects of HRM (for example development and mentoring, improving communication) they would prefer to avoid the less easy elements among which they identify "refusing merit awards, declaring redundancies, resolving grievances and initiating disciplinary action" (p34). While these preferences are apparent in Budhwar's (2000b) investigation into devolvement in UK industry, such a devolutionary trend was apparent in relation to specifically employee resourcing and employee relations activity. 
This reluctance to take on additional HR responsibilities may stem from a perceived or actual lack of competence; line managers may not receive sufficient training to carry out these new roles with confidence (Torrington, 1988; Hope-Hailey et al., 1997). As a result, HRM may need to adopt a more controlling or auditing role to ensure that consistency in treatment is maintained throughout the organisation. Such a position des not sit comfortably with the devolvement of power.

A partnership approach also can be used to manage the HR practices jointly by line managers and HR departments (Eisenstat, 1996; Ulrich, 1997; Ulrich, 1998). Hutchinson and Wood (1995) reported greater line management involvement in personnel issues compared to five years earlier, devolution often being accompanied by decentralization within the organization and with greater local financial autonomy and responsibility. More recently, Hall and Torrington (1998) reported that typically line managers make decisions in conjunction with HR specialists. The 1998 WERS survey (Cully et al., 1999) also found that supervisors were much more likely to play a part in HR-type decisions than they had previously, although it was rare for line managers to have final authority over decision making; a finding largely replicated in the subsequent WERS 2004 survey (Kersley et al., 2005).

To date, most of the studies reporting on the extent of integration and devolvement of HR activities have focussed on Western Europe and North American business. International survey evidence (e.g. Brewster and Larsen, 1992; Brewster et al, 1997) shows that, at least in a European sample, there is a very small number of organizations which have reduced line management responsibility for specific HR issues in the last three years. The overall picture is that for each aspect of human resource management, and each country, there are always 
significantly more organizations increasing line management responsibility than decreasing it.

However this raises questions which are particularly pertinent to this special edition. Namely, that while western contexts dominate the theorising related to employment relations practice, they cannot be considered to represent the dominant underlying cultural values of the majority of industrialising nations. Budhwar and Sparrow's (1997) studies in India mark a significant development in exploring whether such approaches carry over to newly developing economies. Nepal represents a somewhat different context and the next section will explore further the significance of this in relation to the expectations regarding the extent of integration and devolvement of HR practices.

\section{HRM in Nepal}

For many years Nepal was the only Hindu kingdom in the world, although this status was overturned in July 2006, and by a declaration of parliament Nepal is now a secular state. It is a landlocked country highly dependent on its larger and potentially argumentative neighbours of Tibet (China) to the north and India to the south. Its population of some 24 million supports a relatively weak economy: Nepal is the $9^{\text {th }}$ poorest state in the world with an average annual per capita income of only $\$ 1500$ (2006 estimate, CIA, 2007). Since 1990, Nepal has been pursuing a market economy in response to the restoration of democracy after a long period of centralised planning. One major policy reform at this time was the promotion of manufacturing industries, with the new industrial policy of 1992 placing emphasis on deregulation, competition and the influence of market forces and FDI (IIDS, 1996). However, manufacturing still accounts for less than 9\% of GDP (Adhikari, 2005) and the Nepalese economy is closely tied to a single major trading partner; India. Ongoing political instability 
and the underlying weakness of the economy coupled with it's landlocked position, poor infrastructure and heavy reliance on agriculture (38\% of GDP) have severely limited international trade and development (The United States Embassy, 1998). Some 50\% of foreign exchange earnings come in the form of remittances from Nepalese working abroad.

Nepal lacks skilled manpower, literacy in the total population remains at less than $50 \%$ (only $1 / 3$ of the female population is literate). This lack of skilled labour has resulted in very limited uptake of sophisticated technology, therefore the majority of vacancies require low level skills against an unemployment rate of some 15\% (Adhikari 2005). Higher education in Nepal has been expanding in recent years, with business courses being particularly well represented and undergraduate and postgraduate level, however highly educated people are often unable to find suitable employment (Adhikari, 2004).

This somewhat contradictory pattern carries over into the workplace where investment in human resources is not seen as providing benefit to the organisation. Devolvement of responsibility to line managers is likely to be limited both by the prevailing power structures and the limited skills base among those to whom such power could be devolved (Adhikari and Mueler, 2001)

Culturally, Nepal is historically hierarchical (Savada, 1991) and bureaucratic (Pant et al., 1996) with the acquisition of status typically constrained by social class. Adhikari (1999) reports that the overwhelming belief is that the more power you hold, the more you are recognised in society. Such limited cultural assessments of Nepal as have been undertaken indicate a collectivist culture high in power distance, in line with Kanungo and Jaeger's (1990) culture profile of developing countries. The combination of high uncertainty 
avoidance and power distance is reflected in the high status ascribed to public sector employment (Agrawal, 1977; Gautam et al., 2005) and there remains a strong emphasis on centralised administration and management. Political moves to rein in the central bureaucratic systems have tended to serve only to further limit the access of the more skilled professionals to suitable positions.

The overall shape of Nepal's historical, cultural and industrial development would suggest that while the strategic integration of HRM would be attractive, the devolvement of responsibility would be perceived as more problematic. This is supported by a recently published International Executive Report on comparative human resource management (CRANET, 2006). This reveals that around 40 percent of Nepalese organizations have a human resource manager on the main board of directors or its equivalent, although the means by which they obtained this position remains rather opaque; the majority reported not to have been recruited as HR specialists (CRANET 2006, p13). The same survey reports that while 69 percent of organizations have personnel / HRM department, only 21 percent organizations have personnel strategy (Adhikari and Gautam, 2006). According to the CRANET survey data, involvement of HR in business strategy in Nepalese organisations tends to occur in the implementation of that strategy, rather than at its inception or development (43\%), with less than one in three businesses reporting HR involvement in strategy formulation; the lowest proportion of any of the 32 countries on which they report.

It would appear that as a result of this lack of upstream input into strategy formulation, or simply a general absence of HR influence, much of the responsibility for day to day HR activity seems to fall on line management. The CRANET survey (2006) reports that recruitment and selection, pay and benefits, training and development, industrial relations and 
workforce expansion in Nepal are all primarily the responsibility of line management alone. In contrast to this overall picture however, a study of Nepalese commercial banks (Gautam, 2006) reveals that most of the responsibility for HR practices is shared between line management and HR. This degree of joint responsibility may be viewed as encouraging if line managers are increasingly involved in HR related decisions. It is in part stemming from this observation that we have chosen to focus on this sector here.

To summarise, while there are limited data available on HR practices in Nepal, such data as exist indicate that Nepal is at best at an early stage of developing sophisticated human resource management practices. Its operationalisation differs even from its close neighbours of India and China. This study provides insight into how organisations in Nepal may seek to pursue HRM in the future, specifically exploring the nature of integration and devolvement of human resource practices within public listed companies in the Nepalese banking and finance sector. Such organisations may be assumed to be making more attempts to break free of historical ties and traditions. The banking and finance sector specifically has been chosen for this study as it is one of the largest sectors represented on the Nepal stock exchange (currently only 121 public limited companies are listed on the Nepal Stock Exchange). The companies involved share similarities in operation, activities and governance, thus to an extent controlling for sectoral, institutional and business environment factors (Budhwar \& Sparrow, 2002). It is also considered to be the most successful segment of the market, although it remains dominated by domestic rather than international business.

\section{Method}

\section{Sample}


The study focuses on integration and devolvement within the financial sector in Nepal. The potential sample frame consists of 29 public limited companies; 15 commercial banks and 14 insurance companies listed on the Nepal Stock exchange. This represents approximately one in four listed companies in Nepal. Since E-mail and postal data collection methods often prove ineffective in developing countries (Adhikari and Gautam, 2006), one of the authors arranged the time to meet with the senior human resource manager to collect data face to face. This approach also allowed for the clarification of any confusion at the time of meeting. All respondents had obtained a university degree most frequently in business or public administration.

\section{Measurement}

While the data collection took place in an interview format, the interview was structured around a printed questionnaire developed from work by Brewster, Budhwar and colleagues (Brewster and Larsen, 1992; Brewster and Hegewisch, 1994; Budhwar and Sparrow, 1997; Budhwar, 2000a). The first part of the questionnaire sought information on the size, history and makeup of the organisation. The core sections of interest here however was a series of questions relating to the extent to which integration and devolvement of HR strategy and practice took place.

The strategic integration of human resource management practices with business strategy was assessed using four items, in line with the studies cited above. These asked: whether the head of personnel/HR had a place on the main board; whether written HR strategies were in place; whether HR were involved from the outset in formulating corporate/ business strategy; and whether a clear set of work programs existed for the implementation of HR strategy. An 
overall integration measure was calculated by combining these four items such that where a respondent had answered in the affirmative to three or more of the items, the organisation was classified as high integration. Where respondents had provided only 2 or fewer affirmative responses, the organisation was classed as low integration. This is in line with the approach taken by Brewster and Larsen (1992 and Budhwar and Sparrow (1997).

Devolvement was assessed through two sets of items derived from the sources indicated above. First, respondents were asked to identify where primary responsibility lay for implementing a range of HR policy decisions (pay and benefits, recruitment and selection, training and development, labour relations, and workforce expansion or reduction). Options were that responsibility lay with line management alone, with line management in consultation with HR, with HR in consultation with line management or solely with HR. The second group of items asked whether line management responsibility for these areas of activity had increased, decreased or remained the same over the previous 3 years. An overall measure of devolvement was calculated such that where primary responsibility lay with line management alone, or where line management responsibility had increased over the preceding three years, a score of 1 was allocated; otherwise a score of 0 was given. Such an approach has been successfully adopted by Budhwar and Sparrow (1997). Firms scoring more than 5 devolvement responses were categorised as high devolvement, while those with 5 or fewer yes responses were classed as low devolvement.

\section{Results}

\section{Organizational Details}

Data were collected from 26 publicly listed organisations operating within the banking and insurance sectors as described above. Of the 15 listed commercial banks, 14 participated in 
the study, along with 12 of the 14 listed insurance companies. The insurance companies were smaller in size than the commercial banks, all having fewer than 200 employees, while nine of the banks employed more than 200 people. All organisations reported being either in profit or breaking even, but as noted earlier, the bulk of the business in which they were engaged was domestic rather than international. Only two of the banks and one of the insurance companies reported operating in an international market. All organisations were at least five years old, although the oldest had only been founded some 21 years earlier. The commercial banks were significantly older than the insurance companies, on average the banks having been established some 13 years earlier while the insurance companies had typically been in existence for somewhat less than eight years. These data indicate a relatively young and immature financial sector, perhaps inevitably given the troubled history of Nepal and its only recent attempts to industrialise.

Approximately $65 \%$ of employees in the sector were male, a figure that did not vary between banks and insurance companies. Part time working is relatively rare, only being reported in 13 organisations. Where part time workers were employed, the majority (73\%) were female. The age distribution of employees indicates a predominantly younger workforce with $88 \%$ of employees aged below 45 (again consistent between banks and insurance companies). The workforce is a highly educated one, with $42 \%$ or employees having obtained a first degree and a further $30 \%$ having obtained a higher degree. These observations support the assumption made earlier about the likelihood of this sector being more open and responsive to recent developments in management science generally and HR management in particular due to its young and well educated workforce. 
The respondents themselves had been working in their organisation for on average 6 years, and as HR specialists for all of that time. This varied significantly between the banks and the insurance companies, with tenure in both organisation and role significantly higher in the banks than in the insurance companies (organisational tenure 7.5 vs. 4.9 years and role tenure 7.6 vs. 3.9 years). Organisations employed approximately 2 HR staff per 100 employees. This is slightly higher than reported by Brewster and Hegewisch (1994) who identified personnel departments of between 14 and 16 per 1000 employees, however is likely to be influenced by the overall smaller size of the organizations involved in this study. While $90 \%$ of respondents reported using external HR providers, this was predominantly for training and developmental purposes.

\section{Integration}

As noted above, the degree of integration of HR into business and strategy development was construed as a combination of the extent to which HR is represented at board level, the presence of written HR strategy and work programmes for its implementation, and stage at which HR is involved in strategy development. Only three respondents reported having HR represented at board level, of which two were from commercial banks. This situation is in part attributable to the Company Act of 2005, the main act for the regulation of public limited companies. This act declares the composition of the member of Board of Directors and as a result, very few companies include a head of HR on their board. This is out of line with the CRANET (2006) data reported earlier, but as the Act only relates to public limited companies is understandable. Such regulation however may act as a brake on the future development of HR practices in Nepal. 
Written missions statements were in existence in $80 \%$ of respondent organizations, and $77 \%$ had written corporate or business strategies. This is higher proportionately than among the more diverse sample of Nepalese organisations surveyed by CRANET (2006, comparable figures are $69 \%$ and $65 \%$ respectively). The input of HR into the development of business strategy however is rather variable (see Table 1 ). While nearly $40 \%$ of respondent organisations reported that HR was involved "from the outset" in strategy development, the next most frequent response was that HR was merely "consulted when implementing strategies", and in 3 of the insurance companies HR was not involved at all in strategy development or implementation.

Table 1 Involvement of HR in formulating corporate strategy

\begin{tabular}{llll}
\hline $\begin{array}{l}\text { Stage of involvement of HR } \\
\text { department while formulating }\end{array}$ & Banks & Companies & (proportion) \\
corporate strategies & 8 & 2 & $10(38 \%)$ \\
\hline From the outset & 2 & 3 & $5(19 \%)$ \\
Consulted during the process & 4 & 4 & $8(31 \%)$ \\
Consulted while implementing & & & $3(12 \%)$ \\
strategies & 0 & 3 & \\
Not involved & & & \\
\hline
\end{tabular}

Equally significantly, it is apparent from Table 1 that there is variation according to whether the organisation is a commercial bank or an insurance company. In most of the banks HR is involved in strategy formulation from the outset, while in the insurance sector, only 2 out of 12 organisations reported such involvement. Indeed, within the insurance businesses there appears to be little involvement of HR in business strategy at any stage with only a few more 
being consulted on strategy development and the remainder either only being consulted on implementation or not involved at all.

Some $73 \%$ of respondents reported having written HR strategies. Again these were more prevalent in the banks, where 13 out of 14 respondents had written HR strategies (the remaining one reported having an "unwritten strategy"). Only half of the (smaller and younger) insurance companies had written HR strategies, with a further 3 having an unwritten strategy. Overall $42 \%$ of respondents reported having a clear set of work programmes supporting the implementation of HR strategy.

Taken together these data give cause for both optimism and concern regarding the development of strategic HR in the Nepalese financial sector. On the one hand, among the banks the contribution of HR to strategy development appears to be recognised and HR is involved at an early stage. Indeed the involvement of HR in developing corporate strategy in these organisations is higher than reported either by CRANET (2006) or by Budhwar and Sparrow in neighbouring India in 1997 where only $15 \%$ of organisations involved HR at an early stage. On the other hand, the insurance companies seem less concerned about the HR role and integrating HR into corporate strategy, the figures here being comparable to these similar studies. It may be that the size and maturity of the industry is a determining factor here. The commercial banks are both significantly larger and older than the insurance companies, and presumably have therefore been faced with the challenges of coordination and growth to which formalisation of strategy and policy is the usual response (Tayeb, 1987; Hendry and Pettigrew, 1992; Jackson and Schuler, 1995). As a result, HR would appear to be gaining recognition and credibility. In contrast, in the smaller and younger insurance sector HR remains somewhat distanced from core business objectives. It should be noted however 
that Budhwar and Sparrow's sample was selected on the basis of having more than 200 employees, although the finance sector was not included.

An overall measure of integration was calculated as described earlier. Responding in the affirmative to at least three of the four integration items would identify the firm as highly integrated whereas responding negatively to 2 or more items would result in the firm being categorised as low integration. Taking this strict criterion, only 5 organisations would be classified as highly integrated, representing around $20 \%$ of the sample. This is considerably lower than that reported by Budhwar and Sparrow (1997) in their Indian sample, where some $33.6 \%$ fell into the highly integrated category and much lower than Budhwar's subsequent (2000a) UK sample where fully $50 \%$ of organisations (again of 200 or more employees) were highly integrated. Limiting the current sample to only those nine organisations with over 200 employees raised the proportion of highly integrated firms to 33\%, comparable with the 1997 study.

Five organisations do not meet any of the criteria for integration, these all being taken from the insurance sector. Given the purported impact of the 2005 Company Act we removed the requirement of "representation on the Board of Directors" as a criterion for integration. This did not significantly increase the proportion of integrated Nepalese financial services organisations.

The administration of the HR role suggests that awareness of the importance of effective HR is probably fairly high in this sector, although not within Nepalese business as a whole. Senior HR specialists within this sample are predominantly recruited as specialists either from within the organisation (42\%) or externally (27\%). In three of the organisations 
surveyed no Personnel or HR department existed, instead an administrative or corporate department took responsibility for HR issues. While none of these three organisations came out as highly integrated, one did report having a written HR strategy and another reported that the executive most directly responsibly for HR issues sat on the Board of Directors.

\section{Devolvement}

High devolvement is achieved by delivering authority and responsibility for HR activities to line management. In this study, the devolved activities under investigation were pay and benefits, recruitment and selection, training and development, labour relations, and workforce expansion/reduction. The current situation in Nepalese organizations revealed by the data is shown in the table 2.

Table 2 Level of devolved decision-making responsibility in areas of HRM

\begin{tabular}{|c|c|c|c|c|}
\hline & With whom c & s primary responsi & bility lie? (\%) & \\
\hline HR practices & $\begin{array}{l}\text { Sole line } \\
\text { management } \\
\text { decision }\end{array}$ & $\begin{array}{l}\text { Line management } \\
\text { in consultation } \\
\text { with HRM }\end{array}$ & $\begin{array}{l}\text { HRM in } \\
\text { consultation with } \\
\text { line management }\end{array}$ & $\begin{array}{l}\text { Sole HRM } \\
\text { decision }\end{array}$ \\
\hline Pay and reward & $2(7.69)$ & $12(46.15)$ & $10(38.46)$ & $2(7.69)$ \\
\hline $\begin{array}{l}\text { Recruitment and } \\
\text { selection }\end{array}$ & $3(11.53)$ & $11(42.3)$ & $11(42.3)$ & $1(3.8)$ \\
\hline $\begin{array}{l}\text { Training and } \\
\text { development }\end{array}$ & - & $12(46.15)$ & $14(53.85)$ & - \\
\hline Industrial relations & $2(7.69)$ & $10(38.46)$ & $12(46.15)$ & $2(7.69)$ \\
\hline $\begin{array}{l}\text { Workforce expansion } \\
\text { or reduction }\end{array}$ & $5(19.23)$ & $10(38.46)$ & $10(38.46)$ & $1(3.8)$ \\
\hline
\end{tabular}


Most of the responsibility for HR practice is jointly held between line management and HR in consultation. It is rare for either party alone to take major decisions in these areas, and in relation to training, such unilateral action would be unthinkable. It is unclear whether this represents something new, such as development of a partnership approach to HR, whether it is simply a refection of traditional responsibility within a hierarchical context, or whether it is a step on the way to the strategic HRM of which devolvement of responsibility is identified as a core feature. What is more clear is that line management responsibility for these HR areas is on an increasing trend (see Table 3), suggesting that traditional structures are being superseded by more devolved activity. That this shift has only got so far as joint decision making and not yet to fully devolved responsibility is perhaps a representation of the nature of Nepalese society. Traditional hierarchy and the importance of ascribed status remain strong influences on devolution of responsibility. In light of this, it may be that HR specialists in Nepal continue to move more towards a partnership approach than a truly devolved one.

Table 3 Change of line management responsibility in areas of HRM in the last three years (\% of organisations)

\begin{tabular}{llll}
\hline HR issues & Increased & Same & Decreased \\
\hline Pay and Benefits & $15(57.69)$ & $10(38.46)$ & $1(3.85)$ \\
Recruitment and selection & $18(69.23)$ & $8(30.76)$ & - \\
Training and Development & $19(73.07)$ & $5(19.23)$ & $2(7.69)$ \\
Industrial Relations & $11(42.30)$ & $9(34.61)$ & $6(23.07)$ \\
Workforce expansion/reduction & $12(46.15)$ & $11(42.30)$ & $3(11.53)$ \\
\hline
\end{tabular}


Given the rarity of line management being given sole responsibility for HR activities, it is hardly surprising that only three of these organisations would, on basis of the current data, be described as highly devolved. This contrasts with the $33 \%$ of highly devolved organisations found in India (Budhwar and Sparrow, 1997) and 39\% found in the UK (Budhwar 2000a). Closer examination reveals that these three "devolved" companies are in fact relatively small insurance companies without HR departments, therefore it would appear that this "high devolvement" is actually an absence of HR rather than an advanced strategic choice. Indeed all three are low integration companies. Overall, the devolvement score was not significantly different between the high integration and low integration organisations, suggesting that within this sector, these organisations are not pursuing a consistent HRM agenda, and that other factors may be impacting on a clear agenda for people management.

\section{Discussion}

This study sought to clarify the state of development of HRM practices in the Nepalese financial sector. The picture emerging is a confused one, but one which perhaps is interpretable in context. There are a number of key features of this context, namely the maturity of the sector, the nature of ownership of the organisations, and of course the national context in which the study is set. The Nepalese financial services sector is relatively young, although within that, commercial banks have been operating longer than insurance companies. The maturity of an organisation or sector is known to be associated with the formalisation of strategy and policy (Tayeb, 1987; Jackson and Schuler, 1995), and therefore, as would be expected, there is a higher level of formalisation of HR practice in the Banking sector. Within the insurance sector, there appears to be little recognition of the contribution of HR to strategy, and overall the status and influence of HR in these companies is somewhat less. 
However, in comparison to Nepalese business as a whole, as represented by the CRANET (2006) data, the finance sector appears to be more westernised. There is greater expertise and professionalism among senior HR representatives, education levels in general in the sector are high and influence and involvement of HR in strategy formation and implementation exceeds those levels reported in the wider economy. One difference between this sample and the CRANET data is that all the organisations included in this study were publicly listed and subject to a common regulatory framework, including the Company Act of 2005. This imposes some constraints on their operations, including regulating the composition of the Board of Directors. The Act prescribes the composition of the board, and it is particularly relevant here that there is no requirement within the Act for HR representation (although of course such representation is not actually proscribed). Despite this constraint, there appeared little difference in overall integration between those organisations with board level representation and those without.

In the Nepalese service sector, personnel or HR specialists rarely reach the very highest positions in employing organizations. Of course, the degree of HR access to CEO and similar positions varies from organization to organization. It is also true that there are numerous CEOs who may not have come from the personnel function but exhibit a particular interest in HRM. However, these are still exceptions. In practice, an informed HR input to top-level debates is most likely only where the head of the HR functions is a member of the key policymaking forum. According to Purcell (1995) "there is clear, unambiguous evidence that the presence of a personnel director on the main board makes a considerable difference to the role played in corporate strategy" (p78). In Purcell's studies, the presence of such representation was independent of any structural variables, however the strictures of the 
Company Act may indirectly limit direct access to a seat on the board in Nepal and thus inhibit future developments in HR strategy.

While there appears to be evidence of increasing levels of integration within the Nepalese financial sector, particularly if we assume that banking sector will act as a model for an expanding insurance market, the issue of devolvement is somewhat more uncertain. Given the cultural context of Nepal, it is to be expected that those with influence would seek to retain and increase it; giving it away would not be a strategy naturally pursued. Therefore the strong indication in Table 3 that line management is increasing in the extent to which it has devolved responsibility is perhaps counterintuitive. However this again needs to be examined in context. Within a high power distance society where "face" is a significant feature in social interaction, but status is ascribed within a primarily collective, uncertainty avoidant context, the observation of a stated shift in responsibility to line management may represent little more than the acceptable expression of organisational reality. It would be expected that such devolution would not only be counter to the perceived interests of HR specialists, but that it would be resisted also by those to whom responsibility was to be delegated.

Two features of the current context work against this assumption. First, within the organisations surveyed the level of education was very high, and therefore it would be expected that more employees would seek out responsibility and embrace it. A second feature is that in a number of the organisations surveyed, the level of organisational maturity is fairly low and an HR function has not sufficiently developed to the stage whereby some of its core functions need to be devolved. Indeed those organisations where "devolvement" seemed to be at its highest were smaller, newer organisations where HR as a function had not been separately identified and codified. Therefore what appears as devolvement in this 
circumstance is probably better described as taking responsibility, but not actually taking it from anywhere.

Setting such caveats aside, the data do report considerable joint decision making between line and HR, and increases in responsibility for line management regarding HR activities. While overall devolvement is relatively low, certainly compared to measures of integration, such a pattern is not dissimilar to that found in other contexts at higher levels of economic and industrial development. Nepal clearly lags behind Western Europe, and indeed its neighbour India, however the data here to suggest that it is seeking to move towards recognising the centrality and influence of HR in its business operations. This is supported by the difference between this data set and the wider one derived from the CRANET (2006) survey, and by the sectoral differences between banking and insurance companies within the sample.

\section{Limitations of the study}

There are of course a number of limitations to the present study. While the sample represents some $90 \%$ of the population of relevant organisations in Nepal, it remains small in absolute terms. This is unavoidable, and while it could have been increased with other organisations comparable in some respects, the internal consistency of the sample was felt to be worth retaining.

Given the inevitably small sample, there was limited value in pursuing the range of contingent variables identified for example by Budhwar and Sparrow (1997; 2002). While some data were collected on for example organisational size, age and formalisation, seeking to statistically control for these factors would be misleading. Therefore while broad 
demographic data are included, discriminant analysis to determine the influence of these and other contingent variables on overall integration or devolvement was not pursued.

There are two significant omissions from the devolvement scales used here in comparison to those used in other research of a similar design. First, health and safety was not considered as a "devolved activity". Given the occupational context, the precarious nature of existence in Nepal, the strong risk aversion and sense of social obligation, and the limited legal imperatives in this regard it was anticipated that this would not contribute significantly to perceptions of HR activity. This emic approach to scale development does limit comparisons with other relevant data but appropriate adjustments were made to the definition of high and low devolvement to take account of the limited number of variables included.

A more significant difference between this study and others which have used a similar measure was the omission of items relating to the extent to which training had been provided to line managers to enable them to fulfil their HR responsibilities. Previous studies have tended to place limited emphasis on this aspect of devolvement and therefore it was omitted.

In summary, this study indicates that there are discernable shifts within the Nepalese financial sector towards a form of HRM with a recognisably western flavour. The importance of the strategic consideration of HR in particular appears to be gaining some currency within this sector, however the devolution of responsibility to line management as a strategic choice seems to be rather less prevalent. This we argue is in part due to Nepalese cultural pressures, but also to the relatively limited development of the Nepalese economy and its isolation from the wider global community. 
Of course, there remain many situational factors which will inevitably play a greater role in influencing Nepal's economic development, not least the continuing uncertainties surrounding the internal political disputes and the precarious nature of its democracy. It is also a highly diverse country, its population of 25 million being dawn from more than 60 different ethnic groups all seeking to make a living against a backdrop of awe-inspiring beauty and incredible hostility. This study addresses only a small elite of the country's population and over-generalisation must be cautioned against.

Adhikari, D.R. (1999). Human Resource Management in Nepal: Policies and Practices. Innsbruck, Leopold-Franzens-University.

Adhikari, D.R. (2004). Human Resource Environment in Nepal. 5th International Indsutrial Relations Association Congress, Seoul.

Adhikari, D.R. (2005). Labour Legislation and Quality of Work Life in Nepal. 8th Asian Regional Congress of Labour and Social Security Law, Taipei, Taiwan, International Society for Labour and Social Security Law.

Adhikari, D.R. and Gautam, D.K. (2006). "Human resource management in Nepal: Integration and organizational performance", Banijya Sansar - A Journal of Mnagement, Vol. 12 No.

Adhikari, D.R. and Mueler, M. (2001). "Human Resource Management in Nepal", in Budhwar P.S. and Debra, Y.A. (Ed.), Human Resource Management in Developing Countries, Routledge, London, pp. 91-101.

Agrawal, G.R. (1977). Management and Development. CEDA, Kathmandu.

Beer, M., Spector, B., Lawrence, P.R., Quinn Mills, D. and Walton, R.E. (1985). Human Resource Management: A General Manager's Perspective. Free Press, Glencoe Ill.

Boxall, P.F. (1994). "Placing HR strategy at the heart of business success", Personnel Managment, Vol. July No., pp. 32-35.

Brewster, C. and Hegewisch, A., Eds. (1994). Policy and practice in European human resource management: The Price Waterhouse Cranfield Survey. London, Routledge.

Brewster, C. and Larsen, H.H. (1992). "Human Resource management in Europe: evidence from ten countries", International Journal of Human Resource Management, Vol. 3 No. 3, pp. 409-434.

Brewster, C., Larsen, H.H. and Mayrhofer, W. (1997). "Integration and assignment: a paradox in human resource management", Journal of International Management, Vol. 3 No. 1, pp. 1-23.

Budhwar, P.S. (2000a). "Strategic integration and devolvement of Human Resource Management in the UK manufacturing sector", British Journal of Management, Vol. 11 No., pp. 285-302. 
Budhwar, P.S. (2000b). "A Reappraisal of HRM Models in Britain", Journal of General Management, Vol. 26 No. 2, pp. 72-91.

Budhwar, P.S. and Debra, Y. (2001). Human Resource Management in Developing Countries. Routledge.

Budhwar, P.S. and Sparrow, P.R. (1997). "Evaluating levels of strategic integration and devolvement of human resource management in India", International Journal Of Human Resource Management, Vol. 8 No. 4, pp. 476-494.

Budhwar, P.S. and Sparrow, P.R. (2002). "An integrative framework for understanding crossnational human resource management practices", Human Resource Management Review, Vol. 12 No. 3, pp. 377-403.

CIA. (2007). "The World Factbook." Retrieved 3 April, 2007.

CRANET (2006). CRANET Survey on comparative human resource management: international executive report 2005.

Cully, M., Woodland, S., O'Reilly, A. and Dix, G. (1999). Britain at work: as depicted by the 1998 Workplace Employee Relations Survey. Routledge, London.

Eisenstat, R.A. (1996). "What corporate human resources brings to the picnic: Four models for functional management ", Organisational Dynamics, Vol. 25 No. 2, pp. 7-22.

Fombrun, C.J., Tichy, N.M. and Devanna, M.A. (1994). Strategic Human Resource Management. Wiley, New York.

Forster, N. and Whipp, R. (1995). "European Human Resource Management: A Contingent Approach", European Management Journal, Vol. 13 No. 4, pp. 434-442.

Gautam, D.K. (2006). "Sharing of Human Reource Management responsibilities in Nepal", Journal of Management, Nepal, No.

Gautam, T., Van Dick, R., Wagner, U., Upadhyay, N. and J, D.A. (2005). "Organizational citizenship behavior and organizational commitment in Nepal", Asian Journal of Social Psychology, Vol. 8 No., pp. 305-314.

Gennard, J. and Kelly, J. (1997). "The unimportance of labels: the diffusion of the personnel/HRM function", Industrial Relations Journal, Vol. 28 No. 1, pp. 27-42.

Guest, D.E. (1987). "Human Resource Management and industrial relations", Journal of Management Studies, Vol. 24 No. 5, pp. 503-521.

Guest, D.E. (1997). "Human Resource Management and performance: A review and research agenda", International Journal of Human Resource Management, Vol. 8 No. 3, pp. 263-276.

Hall, L. and Torrington, D. (1998). "Letting go or holding on - the devolution of operational personnel activities", Human Resource Management Journal, Vol. 8 No. 1, pp. 41-55.

Hendry, C. and Pettigrew, A.M. (1992). "Patterns of strategic change in the development of Human Resource Management", British Journal of Management, Vol. 3 No., pp. 137156.

Hope-Hailey, V., Gratton, L., McGovern, P., Stiles, P. and Truss, C. (1997). "A Chameleon function? HRM in the '90s", Human Resource Management Journal, Vol. 7 No. 3, pp. 5-18.

Hutchinson, S. and Wood, S. (1995). The UK experience. IPD Personnel and the line: Developing the new relationship. CIPD, London.

IIDS (1996). Nepal, Impact of Economic Liberalization in Nepal. Kathmandu, Institute for Integrated Development Studies.

Jackson, S.E. and Schuler, R.S. (1995). "Understanding Human Resource Management in the context of organizations and their environment", Annual Review of Psychology, Vol. 46 No., pp. 237-264. 
Kanungo, R.N. and Jaeger, A.M. (1990). "Introduction: The need for indigenous management in developing countries", in Kanungo R.N. and Jaeger, A.M. (Ed.), Management in Developing Countries, Routledge, London.

Kersley, B., Alpin, C., Forth, J., Bryson, A., Bewley, H., Dix, G. and Oxenbridge, S. (2005). Inside the Workplace. First findings from the 2004 Workplace Employment Relations Survey (WERS 2004).

Legge, K. (1995). Human Resource Management: Rhetorics and Realities. Palgrave Macmillan, Basingstoke.

Lengnick-Hall, C.A. and Lengnick-Hall, M. (1999). "Strategic Human Resources Management: A review of the literature and a proposed typology", in Schuler R.S. and Jackson, S.E. (Ed.), Strategic Human Resource Management, Blackwell, Oxford, pp. 29-48.

Pant, D.P., Allinson, C.W. and Hayes, J. (1996). "Transferring the western model of project organisation to a bureaucratic culture: the case of Nepal", International Journal of Project Management, Vol. 14 No. 1, pp. 53-57.

Purcell, J. (1995). "Corporate strategy and it's link with Human Resource Management strategy", in Storey J. (Ed.), Human Resource Management: A Critical Text, Blackwell, Oxford.

Savada, A.M. (1991). "Nepal." Retrieved 4 April, 2007, from http://lcweb2.loc.gov/frd/cs/nptoc.html.

Schuler, R.S. (1990). "Repositioning the Human Resource functions: Transformation or demise?" Academy of Management Executive, Vol. 4 No. 3, pp. 49-60.

Schuler, R.S. (1992). "Linking the people with the strategic needs of the business", Organisational Dynamics, Vol. 21 No., pp. 19-32.

Storey, J. (1992). Developments in the Management of Human Resources. Blackwell, London.

Tayeb, M. (1987). "Contingency theory and culture: A study of matched English and the Indian Manaufacturing firms ", Organization Studies, Vol. 8 No. 3, pp. 241-261.

Torrington, D. (1988). "How does human resource management change the personnel function? " Personnel Review, Vol. 19 No. 6, pp. 3-9.

Truss, C., Gratton, L., Hope-Hailey, V., McGovern, P. and Stiles, P. (1997). "Soft and Hard Models of Human Resource Management: A Reappraisal", Journal of Management Studies, Vol. 34 No., pp. 53-73.

Ulrich, D. (1997). Human Resource Champion: The next agenda for adding value and delivering results. Harvard Business Press, Boston MA.

Ulrich, D. (1998). "A new mandate for HR", Harvard Business Review, Vol. 76 No. 1, pp. 124-134.

Whittaker, S. and Marchington, M. (2003). "Devolving HR responsibility to the line. Threat, opportunity or partnership?" Employee Relations, Vol. 25 No. 3, pp. 245-261. 